\title{
ЕКЗИСТЕНЦІАЛ СМЕРТІ В НОВЕЛАХ Е. ПО «МАСКА ЧЕРВОНОЇ СМЕРТІ» ТА «КОРОЛЬ ЧУМА»
}

\begin{abstract}
У статті досліджується специффіка екзистенційного аспекту новел Е. По «Маска Червоної Смерті» й «Король Чума». Моделювання художнього світу творів письменника крізь призму екзистенційних категорій із негативною конотацією тісно пов'язане з психологічною мотивацією дій персонажів і поетикальною специфікою аналізованих текстів.

Мета статті - дослідження екзистениіалу смерті в новелах Едгара По «Маска Червоної Смерті» й «Король Чума». Увага зосереджена на своєрідності домінантного екзистенціалу смерті, який супроводжується такими філософсько-екзистенційними аспектами, як тривога, страх, відчай тощзо. В аналізованих творах спостерігаємо миттєвий перехід від тривоги до страху. У ицьму випадку страх перед смертю, у хвилини найбільшої небезпеки стає панічним, він паралізує людину.

У результаті дослідження було з 'ясовано, щзо автор змальовує категорію смерті за допомогою різних художніх прийомів (символізачія, метафоризація, контраст, порівняння, звукове й одоративне наповнення, гротеск). Задля забезпечення атмосфери таємничості Е. По використовує алегорії, контраст, ефект опису світла й особливості інтер 'єру. Крім того, з'ясовано, щуо мотив смерті у творах посилюється обмеженим хронотопом, який реалізується в образі замку й кімнати-трунарні, образом гігантських дзитарів $і$ змалюванням химерного карнавалу («Маска Червоної Смерті»), не менш незвичайного бенкету й фантастичним зміщенням світів («Король «Чума»). Обмежений простір у новелах характеризується уповільненою темпоральністю та одностайністю. Часопросторова площина аналізованих новел збігається, адже містичний і реальний світи змагаються між собою за право володарювання.

Образ смерті в новелах персоніфікований, смерть є надприродною силою, яка кожного разу приміряє на себе різні образи й розраховує на суцільне завоювання, проте герої творів ведуть боротьбу до останнього подиху.

Ключові слова: екзистенціалізм, екзистенціал смерті, контраст, метафора, символізачія, інтер'єр, хроноmon.
\end{abstract}

Nadiya PAVLIUK, orcid.org/0000-0001-7170-5743 Ph.D. in Philology,

Lecturer at the Department of Ukrainian and World Literatures South Ukrainian National Pedagogical University named after K. D. Ushinsky (Odesa, Ukraine) pavlyuknadya@gmail.com

\section{EXISTENTIAL OF DEATH IN E. POE'S SHORT STORIES “THE MASK OF RED DEATH" AND "THE KING OF THE PLAGUE"}

The article examines the specifics of the existential aspect of E. Poe's short stories "The Mask of the Red Death" and "The King of the Plague". Modeling the artistic world of the writer's works through the prism of existential categories with a negative connotation is closely related to the psychological motivation of the characters'actions and the poetic specificity of the analyzed texts.

The purpose of the article is to study the existential of death in Edgar Allan Poe's short stories "The Mask of the Red Death" and "The King of the Plague". Attention is focused on the originality of the dominant existential of death, which is accompanied by such philosophical and existential aspects as anxiety, fear, despair, and so on. In the analyzed works we observe an instantaneous transition from anxiety to fear. In this case, the fear of death, in moments of greatest danger becomes panic, it paralyzes a person.

The study found that the author depicts the category of death using various artistic techniques (symbolization, metaphorization, contrast, comparison, sound and odorous content, grotesque). To ensure an atmosphere of mystery, E. Poe uses allegories, contrast, the effect of describing light and interior features. In addition, it was found that the motif of death in the works is enhanced by a limited chronotope, which is realized in the image of a castle and a coffin 
room, the image of a giant clock and depictions of a bizarre carnival ("The Mask of the Red Death"), no less unusual feast and fantastic shift of worlds ("The King of the Plague"). Limited space in short stories is characterized by slow temporality and unanimity. The space-time plane of the analyzed short stories coincides, because the mystical and real worlds compete with each other for the right to rule.

The image of death in the short stories is personified; death is a supernatural force, which each time tries on different images and expects a continuous conquest, but the heroes of the works are fighting to the last breath.

Key words: existentialism, existential of death, contrast, metaphor, symbolization, interior, chronotope.

Постановка проблеми. Характерною особливістю творчості Едгара По є вплив філософії екзистенціалізму на формування поглядів письменника, в центрі яких - людина та ії проблеми. Літературознавець I. Василишин зазначає, що «<..> в основі екзистенціалістського мислення лежить «вроджена» схильність до письменницького бачення світу, тобто зосередженості на «вічних загадках» життя та смерті, осмисленні дійсності через iï напружене переживання (дійсність трактується як «існування», трансформоване через внутрішне «я»), акцентуванні уваги на індивідуальному самовираженні людини тощо» (Василишин, 2003: 70).

Провідними концептами, які окреслюють екзистенційні виміри творчої спадщини Едгара По, є страх, самотність, відчай, смерть, тривога, тобто екзистенціали негативного характеру.

Аналіз досліджень. У центрі уваги дослідників творчої спадщини Е. По (Ф. Достоєвського, В. Брюсова, Р. Грізвольда, Ш. Бодлера тощо) неодноразово були проблеми жанру, стилю, поетики творів автора, були поодинокі розвідки екзистенційного аспекту новел Е. По, проте грунтовного аналізу окремих екзистенційних модусів не було здійснено в сучасному літературознавстві.

Метою статті $\epsilon$ дослідження екзистенціалу смерті в новелах Едгара По «Маска Червоної Смерті» й «Король Чума».

Виклад основного матеріалу. У художній творчості Едгара По помітні елементи філософії екзистенціалізму, яку з художньою літературою пов'язує «<...> унікальність людини, філософія життя, гуманізм, питання свободи й відповідальності, смерті, часу <..>> (Бугайова, 2011: 55). У зв'язку із цим письменник порушує актуальні філософські питання про зміст людського існування, радість життя та страх смерті тощо.

В екзистенційній філософії проблемі смерті відводиться помітне місце, тому що вона «<... займає в розумінні людини центральне місце як виняткова обставина, яка зумовлює напруженість особистого буття в його остаточній нестерпності〉 (Бугайова, 2011: 60).

У творах Е. По екзистенціал смерті пронизує критичні, межові ситуації життя персонажів. Так, категорія смерті постійно присутня в новелі
Едгара По «Маска Червоної Смерті», адже давно «<..> вже спустошувала країну Червона Смерть» (По, 2001). Перше речення новели занурює читача в атмосферу страху, яка породжує інтерес і налаштовує на незвичайний розвиток сюжету. Автор детально змальовує хворобу, якій ніхто не міг протистояти, як ситуацію випробувального характеру, яка змушує людей замислитися над життям, переоцінити життєві цінності й перейти на новий щабель існування. «Страх смерті має величезне значення в нашому внутрішньому досвіді: він переслідує нас як ніщо інше, постійно нагадує про себе якимсь «підземним гуркотом», ніби дрімає вулкан. Це - темна, тривожна присутність, що причаїлася на краю свідомості» (Ялом, 2008: 253). Саме тому, бажаючи врятувати своє життя, принц Просперо, який i «<..> далі розкошував життям, непіддатливий страху <...> (По, 2001), вирішив разом зі своїми друзями усамітнитися, «<..> відмежувавшись від світу в одному зі своїх монастирів-замків» (По, 2001). Здається, що юнак живе своїми ілюзіями, намагаючись якомога далі сховатися від долі. Він ніби бунтує проти такої небезпечної перспективи: «Задуми його були сміливі й натхненні й втілювалися 3 варварською розкішшю. Дехто назвав би його безумцем, проте наближені до нього гадали інакше. Слід було чути, бачити, бути поруч, аби впевнитися, що розум йому не потьмарився» (По, 2001). Принц створив, не дивлячись на досить скрутну ситуацію в країні, бурливу жахливу хворобу чуму, у своєму замку абсолютно інший яскравий світ веселощів i бенкету. 3 цього моменту спостерігаємо поділ просторової структури твору на дві частини за допомогою звернення письменника до бінарних просторових опозицій «тут»/«там». В експозиції новели дія контрастно відбувається в просторових координатах замку й за його межами: «Принц подбав, аби не бракувало розваг. Тут були блазні й імпровізатори, танцівники й музики, Краса й п'янкі трунки. Усе це разом з безпекою було тут, у монастирському захистку, а там, назовні, панувала Червона Смерть» (По, 2001). Тож автор створює у творі двосвітовість, де світ життя протистоїть світу смерті, а Просперо й Смерть $\epsilon$ ніби головними суперниками-повелителями. 
Новела 3 алегоричним змістом Едгара По «Король Чума», в якій продовжується тема чуми, це поєднання фантастичного світу з реальністю без чітких кордонів. Головними героями твору $є$ два моряки - Голобля та Г'ю Просмолений, портрети яких яскраво контрастують між собою: «Той iз них, хто був нібито старший і кого його товариш цілком заслужено звав Голоблею, відзначався і справді височезним зростом. Вигнався він чи не на шість футів із половиною, то й не дивно, що весь час горбився. А втім, надмір довжини більш ніж треба відшкодовувався браком ширини. Був він такий худющий, що, як запевняли товариші, п'яний міг правити за вимпел на щоглі, а тверезий - за бушприт» (По, 2001) i «Молодший моряк, хоч $з$ якого боку подивися, у всьому здавався цілковитою його протилежністю. Росту в ньому було не більше чотирьох футів. Коротенький оклецькуватий тулуб тримався на кривих ногах - цурбанчиках ; незвичайно куці й товсті руки з неймовірно великими кулаками теліпалися по боках, наче плавці морської черепахи. Маленькі, ніякої барви очиці поблискували десь глибоко-глибоко в голові» (По, 2001). Образи моряків постають як абсолютна протилежність один одному, й не дарма автор обрав персонажів саме цієї категорії, адже моряки - люди відчайдушні, вони пліч-опліч зустрічалися зі смертельними небезпеками й раніше. Після посиденьок у пивниці й з'ясування факту відсутності грошей починаються пригоди моряків та їхня безпосередня зустріч зі смертю.

Однією з психологічних загадок, що постійно приваблювала до себе увагу Е. По, - схильність людини до порушення заборони. Тож головні герої новели, рятуючи своє життя втечею від власників пивниці, незважаючи на заборону заходити до зачумлених кварталів, все ж біжать саме туди: «Вони без вагань шугонули вниз на заборонену землю і незабаром, біжучи все далі, куди п'яні ноги несли, гагакаючи й пугукаючи, загубилися в плутанині смердючих завулків» (По, 2001). Райони, окутані хворобою, письменник змальовує 3 художньою точністю: «Вулиці були захаращені уламками зруйнованих будинків. Повсюди стояв задушливий, отруйний сморід, і при мертвотноблідому світінні, яке навіть глупої ночі соталося 3 імлистого, зараженого повітря, можна було розгледіти просто на вулицях, чи в бічних провулках, чи в оселях із вибитими вікнами - трупи нічних грабіжників $<\ldots>$. $(П о, 2001) ;$ «<..> по темних, вузьких, брудних вуличках і закутках, де, як гадали, й з'явився на світ Демон Чорної Моровиці, привільно гуляли самі лише Жах, Страх і Забобон» (По, 2001). Перед читачем відкривається правдивість умов соціального світу під час розповсюдження смертельної хвороби, що забезпечує ефект напруженості уяви. У творі спостерігаємо також яскравий опис кімнати, що була твердинею чуми, й саме в ній бенкетував Король Чума: «Кімната, до якої вони потрапили, виявилась крамницею трунаря; однак через відчинену ляду в кутку біля входу виднів довгий ряд винних льохів, а бахкання корків, які час від часу вилітали 3 пляшок, засвідчувало, що там зберігаються чималі припаси хмільних напоїв» (По, 2001). Таким чином автор показує контрастність між навколишнім середовищем і бенкетом товариства. Кульмінаційним моментом новели $є$ винесення Королем Чуми вироку морякам: «Одначе за те, що ви так по-блюзнірськи вдерлися в нашу раду, ми вважаємо за свій обов' язок накласти пеню на тебе й на твого товариша: ви повинні, ставши навколішки, вихилити одним духом за процвітання нашого королівства по галонові рому, змішаного 3 патокою, після чого можете або йти собі далі своєю дорогою, або ж лишитися та зажити разом 3 нами радощів нашої учти, - вже як то душам вашим буде завгодно» (По, 2001), Здається, що розв'язка очевидна, проте Едгар По приготував зовсім інший вихід із ситуації. Між головними героями Г'ю Просмоленим і Голоблею та мешканцями іншого світу велася справедлива боротьба, де все ж таки перемогу отримали моряки.

Сюжет новели «Маска Червоної Смерті» повністю чіткий. Тут немає нічого, що могло б заплутати уяву читача. Усі елементи складають єдине ціле. Художній час і простір збігаються. Крім експозиції (чума в країні й відгородження принца Просперо від проблеми), події розгортаються протягом одного вечора й тривають до півночі. Черговий бій годинника, як писав Ю. Ковальов, позначає головні моменти розвитку дії (Ковальов, 1984, 215). Це є своєрідним нагадуванням про скінченність людського життя. Саме звук дзигарів вселяс жах у душі гостей. У зав'язці твору автор детально описує маскарад і шість барвистих кімнат, які передають відчуття насолоди життям. Останньою зі списку продемонстрованих покоїв була чорно-багряна: «Сьому кімнату було запнуто чорним оксамитом: чорне драпірування збігало тут від самісінької стелі й важкими згортками спадало на килим із такого ж чорного оксамиту. I лише тут вікна не повторювали барвів оздоблення: вони були багряні - густого кольору крові. У жодній із семи кімнат, серед рясноти золотих прикрас, розкиданих тут і там, - а деякі звисали навіть зі стелі, - не видно ні люстр, ані канделябрів. Ніде у внутрішніх покоях не світилось ні лампи, ні свічки» (По, 2001). Ця, сьома, кімната своїм інтер'єром асоціювалася з трауром, 
скорботою та смертю. Ї̈ї поріг боялися переступати, можна сказати, що вона була своєрідним символом, що нагадував про трагедію за стінами замку. Саме в ній відбувається кульмінаційна сцена твору. Цифра «сім» співвідноситься з поняттям семи смертних гріхів, які наближали зустріч правителя одного світу з іншим. Кольори кімнат своєю чергою символізують різні етапи життя: від блакитного (новонародженості) до чорного (смерті). Розв'язка новели - поєдинок і раптова смерть принца - неочікуваний аспект, який додає напруженості моменту кульмінації. Саме таким чином Едгар По доводить читачеві, що страх смерті - найсильніше відчуття, яке може сприймати людина. Підтвердженням цьому $є$ думка дослідниці І. Тищенко, що «<...> страх смерті й страх нереалізації власного життя - одне з тотальних відчуттів людини» (Тищенко, 2011: 375).

Акцентованим елементом твору «Маска Чорної Смерті» $є$ опис страшної хвороби чуми, від якої помирало населення: «Колючі болі, раптове запаморочення, а далі кров пирсне 3 усіх пор - i прощавай, білий світе. Криваво-червоні плями на тілі, а надто на обличчі - ознака зарази, й годі тоді їі жертві сподіватися на допомогу чи то співчуття своїх ближніх. Недуга була скоробіжна: від перших спазмів до смертних корчів минало не більш як пів години» (По, 2001). Образ смерті в новелі персоніфікований, смерть спустошує, панує, шаленіє, «<...> кров була iï знаком і тавром - жаска багряниця крові» (По, 2001). Кров це «<... символ життя; душі; сили омолодження; в християнстві - життя тіла й духу. У Біблії кров символ душі; прообраз іншої вищої крові; кров подібна за символічним навантаженням до червоного кольору, вогню; вона - знак пристрасті, повноти життя, активності, свободи, а 3 іншого боку - смерті, агресивних намірів, війни, помсти <...>» (Словник символів, 1997). Символічне навантаження образу крові й червоного кольору в аналізованому тексті взаємопов'язане й несе в собі негативну конотацію, тому що $є$ уособленням смерті. У розв'язці твору образ смерті набуває рис цілком конкретної людини. Смерть «<..> переважно аналогізували з особою жіночої статі. Чому сприяла родова належність іменника смерть. Модель жінка-смерть є концептуальною метафорою, яка сформувалася в міфології» (Кравець, 2012: 246). Однак у новелі «Маска Червоної Смерті» Е. По під час маскараду, який організував принц Просперо, смерть з'являється в образі чоловіка: «Заброда був довготелесий, худий і 3 голови до п'ят закутаний у саван. Маска, за якою ховалося його обличчя, так нагадувала задубілий вид мерця, що навіть найпильніший і найдоскі- пливіший погляд заледве міг би розпізнати оману. Зрештою, навіть таке простили б йому розшалілі веселуни, а то, може, й схвалили б цю витівку, якби штукар не зайшов аж так далеко, зухвало напнувши на себе личину Червоної Смерті. Одіж його була зарошена кров'ю, і широке чоло й усе лице покроплене жаскою багряницею» (По, 2001).

Образ смерті в новелі «Король Чума» цілком реалістичний, набуваючи рис конкретної людини чоловічої статі, він реалізується в образі Короля Чуми: «Якраз Навпроти дверей, трохи вище за інших, сидів, напевне, старший того застілля. $<\ldots>$ Обличчям він був жовтий, мов шафран $<\ldots>$ Його губи кривилися посмішкою диявольської приязні, а очі, як, зрештою, у всіх бенкетарів, були осклілі від винних випарів. Цей пан був із голови до п'ят закутаний у чорний, пишно розшитий оксамит, що ним покривають труни, - недбало обкрутився ним, неначе іспанським плащем» (По, 2001). 3 метою доповнення образу смерті автор звертається до одоративних образів, які були характерними для ï просторових володінь: «<..> задушливий, отруйний сморід <...> (По, 2001), «<..> повітря робилось дедалі смердючіше та ядучіше <..>» (По, 2001), запахи ще не зовсім розкладених трупів. Крім того, досить незвичайними $є$ портретні характеристики й гостей Короля Чуми. У цій гротескній картині сконцентровані стилістичні прийоми - сплетіння жахливого й комічного, інтерес до деталі, дивина фантастичних образів. У кожного учасника нічного бенкету певна частина обличчя відіграє домінівну роль. У самого Короля - це лоб: «Чоло в нього було таке потворно високе, що здавалося, ніби на голову йому ще додатково насадили шапку чи вінок із плоті» (По, 2001), у дами, що слабувала на водянку, - рот: «Починаючись біля правого вуха, він зяяв страхітливою щілиною аж до лівого, й не такі вже й довгі її сережки знай заскакували в те провалля» (По, 2001). Не менш привабливими $\epsilon$ портретні характеристики й інших гостей бенкету. Містикою сповнений і сам діалог між Королем Чуми й моряками. Король говорить із величністю, його мова лаконічна й милозвучна: «Ми з великою охотою задовольнимо цікавість таких високих, хоч і непроханих гостей і дамо відповідь на будьяке розумне запитання. Тож знайте: я - монарх усіх цих володінь і правлю тут єдинодержавно під ім'ям король Чума» (По, 2001).

У творі Е. По «Маска Червоної Смерті» прослідковується тенденція метафоризації життя до символічного образу маскараду, який організував принц у замку. Це підкреслює не лише загальний філософський зміст твору митця, але й визначає філософське підгрунтя людської екзистенції. Мас- 
карад - це своєрідний виклик тому, що відбувалося за межам замку, виклик смерті. Змалювання людей, що танцюють на балі-маскараді, переодягнені в різні костюми, нагадує вир життя, який із великою швидкістю проноситься повз: «Там було багато гарного, багато вкрай розперезаного, багато bizarre, трохи чогось страхітливого й чимало такого, що мимоволі викликало огиду. Повсюдно в семи світлицях юрмилися примари. Вони - ці примари - роїлися тут і там, корчились, мелькали то в тій, то в тій кімнаті, просякнувши ії барвами, й здавалося, наче звуки дикої музики - то лише відлуння їхньої ходи» (По, 2001). У новелі «Король Чума» автор також змальовує бенкет, але дещо в інших тонах. Це було свято на честь смерті: «<..> задля справдешнього процвітання тієї неземної володарки, що панує над усіма нами, володіння чиї безмежні, а ім'я їй - Смерть!» (По, 2001). Відповідними є і місце дії - трунарня, і атрибути бенкету: черепи, що правили за келихи, підставки для трун замість стільців, « $<. .>$ над столом висів людський скелет - він погойдувався на мотузку, обв'язаному навколо ноги й просмикнутому через кільце в стелі. <..> У черепі тієї мерзоти палало вугілля, кидаючи непевне, хоч і яскраве світло на всю сцену, а труни й інші товари трунаря, складені купами попід стінами й вікнами, не пропускали на вулицю жодного проблиску» (По, 2001). Тож протистояння життя та смерті, визначення їхнього екзистенційно-онтологічного підгрунтя $\epsilon$ домінівним у творах Едгара По.

Символічним образом новели «Маска Чорної Смерті» є образ гігантських дзигарів: «I час від часу із зали, оздобленої чорним оксамитом, долинав бій дзигарів. I тоді на хвильку все ціпеніло й змовкало - усе, крім голосу дзигарів, - а фантастичні істоти вклякали на місці, там, де їх той голос заскочить. Та ось відлунає подзвін - а чути його лише мить - i одразу веселий, ледь притлумлений сміх попливе навздогін за даленіючим дзвоном; і знову гримить музика» (По, 2001). Вибиваючи годину за годиною, ебеновий годинник ніби відраховує час смерті, що посилює психологічне напруження, адже 3 кожним новим ударом дзигарів збільшується відчуття наближеності до чогось таємничого й невідомого. «Часовий ритм, організований як рухи героїв, має фізіологічний аналог: уповільнення та прискорення пульсу. Ритм годин у «Маска Червоної Смерті» нагадує серцебиття. В оповіданні йдеться про гарячкове биття «серця» життя в кімнатах абатства» (Гуральчук, 2015). Дійсно, визначальним для досліджуваного твору $€$ контрастне поєднання пришвидшення (розваги, вальсування під час маскараду) з одночасним упо- вільненням (завмирання всього в момент появи незнайомця) часу: «Усі інші кімнати переповнені, в них гарячково нуртує життя. Свято було в повному розпалі, коли дзигарі почали відбивати північ. I тоді, як уже й розповідалося, стихла музика, завмерла круговерть вальсу й усіх опанувала якась невиразна тривога. Цього разу ебенові дзигарі мали вибити дванадцять ударів, i, може, тому що довше вони били, то дужче закрадалася тривога навіть у душі найрозважливіших. Через те, либонь, не встигло здаленіти останнє відлуння останнього удару, як багато хто з присутніх зненацька побачив маску, котрої досі ніхто не помічав» (По, 2001). У зазначеному епізоді екзистенційна категорія тривоги сповнена невідомості, збентеженості. Варто зауважити, що тривога породжує страх, тобто почуття тривоги є первинним, а стан страху - вторинним. Страх, на думку дослідниці I. Тищенко, «<...> не можна ототожнювати 3 тривогою. Страх - це цілком визначена, специфічна емоція, це переживання, що виникає з очікування загрози або небезпеки. Тривога - це почуття наскрізне, неперебутнє, воно завжди присутнє у світі, де щезає надія» (Тищенко, 2011: 375). До того ж тривога пов'язана зі збентеженням, передчуттям небезпеки. У творі спостерігаємо миттевий перехід від тривоги до страху: тривога, невдоволення, подив, страх, переляк, огида («Чутка про появу нової маски враз облетіла всіх гостей, іiі передавали пошепки з уст в уста, аж поки загулозагомоніло все зібрання, виказуючи на початку невдоволення та подив, а далі - страх, переляк та огиду» (По, 2001)). За психологом 3. Фрейдом, тривога «<...> має безсумнівне відношення до очікування < ..> Їй притаманна властивість невизначеності й безоб'єктності; якщо вона знаходить об'єкт, правильне слововживання саме змінює іiі назву, в такому випадку замінюючи ії страхом» (Фрейд, 2006, 302). В описаному епізоді тривога спричинює страх глибоко на підсвідомому рівні, а зовнішньо це проявляється через небажання будь-якої діяльності. У цьому випадку страх перед смертю у хвилини найбільшої небезпеки стає панічним, він паралізує людину: «Це відбувалось у блакитній залі, де стояв принц Просперо серед гурту блідих придворних. Зачувши його повеління, вони кинулись до непроханого гостя, котрий теж був неподалік, однак той раптом спокійною, впевненою ходою попрямував до принца. Ніхто не зважився підняти на нього руку - такий незбагненний жах навіювала зарозумілість цього шаленця» (По, 2001), «<..> але так ніхто й не зробив рішучої спроби його перепинити. I тоді принц Просперо, охоплений нестямною люттю та 
соромом за свою миттєву нерішучість, метнувся за ним навздогін через шість покоїв, і ніхто з придворних не зрушив із місця, бо всіх скував смертельний жах» (По, 2001). Можливо, й сам принц боявся непроханого гостя, адже його зовнішній вигляд був надзвичайно страшним та асоціювався зі смертю, однак Просперо був господарем замку, він змушений був чинити опір. Крім того, емоція страху «<... може мати як стенічний, так і астенічний характер» (Степанов, 2006: 183): стенічний страх спонукає до мобілізації всіх сил, до рішучих дій, а астенічний, навпаки, пов'язаний із безсиллям людини, iї нерішучістю. Можна сказати, що принц під впливом стенічного страху «< ..> біг 3 оголеним кинджалом, стрімко й грізно, й коли на порозі чорної кімнати вже майже наздогнав свого супротивника, той зненацька обернувся та встромив у нього погляд» (По, 2001). Рішучість господаря замку призвела до його загибелі: «Злинув пронизливий зойк - і кинджал, зблиснувши, впав на жалобний килим, на якому за мить розпростерлося тіло мертвого принца» (По, 2001).

Як відомо, смерть «<...> зазвичай викликає в людини страх через свою невідворотність, непередбачуваність і відсутність досвіду вмирання <..>» (Кравець, 2012: 249). Однак у новелі «Король Чума» моряки, потрапивши на смертельний банкет, познайомившись із Королем Чумою та його товариством, взагалі не відчувають ніякого страху: «Треба сказати, що наші моряки, уздрівши таке незвичайне товариство й ще незвичайніше одіння та начиння, повелися далеко не так гідно, як того можна було від них сподіватися. Голобля, прихилившись до стіни, під якою стояв, роззявив рота, відкопиливши спідню губу ще більше, ніж завжди, а очі йому трохи на лоба не вилізли; тим часом Г’ю Просмолений, присівши так низько, що ніс його опинився на одному рівні зі столом, і ляскаючи себе долонями по колінах, вибухнув нездержним i дуже недоречним реготом» (По, 2001). Екзистенційність головних персонажів криється в тому, що вони усвідомлюють наближення можливої смерті, але їм це не перешкоджає боротися до кінця, який стає для них переможним. Підсиленню думки щодо абсурдності смерті сприяе й епіграф, дуже влучно підібраний Едгаром По: «У чім потурають королям богове, того не зносять у голоті ницій» (По, 2001). Те, що для верхівки стало забороною, для людей низів (моряків) стає свободою дії. Саме тому в аналізованому творі основою життєвої філософії моряків $є$ боротьба за життя, адже, як стверджує філософ А. Камю, в повстанні, тобто в боротьбі, ми існуємо (Камю,
1990: 22). І в той момент, коли Г’ю Просмоленого іiі величність Ротяка «<...> безцеремонно пожбурила у величезне відкрите барило з його улюбленим жовтневим пивом» (По, 2001), де він «<..> протягом кількох секунд $<\ldots>>$ то поринав на дно, то виринав, мов яблуко в келиху з пуншем, аж поки щез у вирі пінявого напою, що від його відчайдушного борсання завирував ще дужче» (По, 2001), його товариш Голобля починає боротьбу з Королем Чуми, в результаті якої моряки отримали перемогу.

Вирішальним епізодом новели «Маска Червоної Смерті» стає зривання «маскарадного» костюма 3 незнайомця, під яким виявилася інфернальна порожнеча: «Та щойно вони вчепились у лиховісного штукаря, чия довга постать витяглась непорушно й зачаїлась у тіні від ебенових дзигарів, як од невимовного страху їм забило дух, бо під могильним саваном і безживною маскою, що їх вони смикали з такою нестямною люттю, не було нічого - сама порожнеча < .. >» (По, 2001). Контраст між веселим (маскарад) і жахливим (смерть під маскою) є гротеском, який складає основу розповіді. Смерть забрала життя всіх присутніх. Містичний фінал «Маски Червоної Смерті» був введений Едгаром По недарма, він конструювався через образи, згадані раніше.

Висновки. Як бачимо, мотив смерті домінує в новелах Едгара По «Маска Червоної Смерті» й «Король Чума». Провісницею смерті є Чума, а вона має намір забрати якомога більше життів людей. Категорія смерті у творах автора супроводжується такими філософсько-екзистенційними аспектами, як тривога, страх, відчай тощо. Автор зображує моторошні картини за допомогою різних художніх прийомів (символізація, метафоризація, контраст, порівняння, звукове й одоративне наповнення, гротеск), показуючи, що смерть завжди напоготові. Часопросторова площина аналізованих новел збігається, адже містичний і реальний світи змагаються між собою за право володарювання. Мотив смерті у творах посилюється обмеженим хронотопом, який реалізується в образі замку й кімнати-трунарні, образом гігантських дзигарів і змалюванням химерного карнавалу («Маска Червоної Смерті»), не менш незвичайного бенкету й фантастичним зміщенням світів («Король «Чума»).

Головні персонажі новел Едгара По потрапляють у нестандартні ситуації та регламентують свободу власного вибору, доводячи абсурдність страху смерті. Тож в аналізованих творах письменника онтологічна спрямованість боротьби за життя, протистояння смерті є пріоритетним. 


\section{СПИСОК ВИКОРИСТАНИХ ДЖЕРЕЛ}

1. Бугайова Н. Сутність людської особистості провідний мотив новели В. Шевчука «Біла нитка печалі». Теоретична і дидактична філологія : збірник наукових праць. Київ : ДП «Інформаційно-аналітичне агенство», 2011. Вип. 10. С. 54-61.

2. Василишин І. Віртуальний світ українського екзистенціалізму (Ю. Косач і В. Домонтович). Слово i час. 2003. № 6. С. 70-75.

3. Гуральчук Н. Специфіка мотиву смерті у новелі Е. А. По «Маска Червоної Смерті». Полілог. 2015. № 3. С. $32-34$. URL: http://eprints.zu.edu.ua/19674/1/Guralchuk.pdf.

4. Камю А. Бунтующий человек. Философия. Политика. Искусство. Москва : Политиздат, 1990. 415 с.

5. Ковалёв Ю. Эдгар Аллан По. Новеллист и поэт. Ленинград : Худож. лит., 1984. 296 с.

6. Кравець Л. Динаміка метафори в українській поезії XX ст. Київ : ВЦ «Академія», 2012. 416 с.

7. По Е. Чорний кіт: Оповідання. Київ : Дніпро, 2001. 368 с. URL: http://e-bookua.org.ua/detektiv/229-po-e-aopovdannya.html.

8. Словник символів / О. Потапенко, М. Дмитренко, Г. Потапенко та ін. ; за заг. ред. О. Потапенка та М. Дмитренка. Київ : Редакція часопису «Народознавство», 1997. 156 с. URL: https://studfile.net/preview/5252915/.

9. Степанов О. Основи психології і педагогіки : навчальний посібник. Київ : Академвидав, 2006. 520 с.

10. Тищенко І. Екзистенціал страху в романі Р. Андріяшика «Люди зі страху». Теоретична і дидактична філологія : збірник наукових праць. Київ : ДП «Інформаційно-аналітичне агентство», 2011. Вип. 10 С. 374-384.

11. Фрейд 3. Собрание сочинений : в 10 томах. Москва : СТД, 2003-2008. Т. 6 : Истерия и страх / пер. с нем. А. Боковикова. 2006. 320 с.

12. Ялом И. Вглядываясь в солнце. Жизнь без страха смерти. Москва : Эксмо, 2008. 352 с.

\section{REFERENCES}

1. Buhaiova N. Sutnist liudskoi osobystosti providnyi motyv novely V. Shevchuka "Bila nytka pechali" [The essence of the human personality is the leading motif of V. Shevchuk's short story "White thread of sorrow"]. Teoretychna i dydaktychna filolohiia. Kyiv : DP “Informatsiino-analitychne ahentstvo", 2011. № 10. Pp. 54-61. [in Ukrainian].

2. Vasylyshyn I. Virtualnyi svit ukrainskoho ekzystentsializmu (Iu. Kosach i V.’Domontovych) [Virtual world of Ukrainian existentialism (Yu.’Kosach and V.’Domontovych)]. Slovo i chas. 2003. № 6. Pp. 70-75. [in Ukrainian].

3. Huralchuk N. Spetsyfika motyvu smerti u noveli E. A. Po "Maska Chervonoi Smerti" [The specifics of the motive for death in the novel by E. A. Poe “The Mask of the Red Death”]. Poliloh 2015. № 3. Pp. 32-34. URL: http://eprints.zu.edu. ua/19674/1/Guralchuk.pdf [in Ukrainian].

4. Kamyu A. Buntuyuschiy chelovek. Filosofiya. Politika. Iskusstvo [Rebellious man. Philosophy. Politics. Art]. Moskva : Politizdat, 1990. 415 p. [in Russian].

5. Kovalyov Yu. Edgar Allan Po. Novellist i poet. [Edgar Allan Poe. Novelist and poet]. Leningrad : Hudozh. lit.1984. 296 p. [in Russian].

6. Kravets L. Dynamika metafory v ukrainskii poezii XX st. [Dynamics of metaphor in Ukrainian poetry of the XX century]. Kyiv: VTs “Akademiia”, 2012. 416 p. [in Ukrainian].

7. Po E. Chornyi kit: Opovidannia [Black Cat: Stories]. Kyiv: Dnipro, 2001. 368 p. URL: http://e-bookua.org.ua/detektiv/229-po-e-a-opovdannya.html [in Ukrainian].

8. Slovnyk symvoliv / [Potapenko O. I., Dmytrenko M. K., Potapenko H. I. ta in.]; za zah. red. O. I. Potapenka ta M. K. Dmytrenka. [Dictionary of symbols]. Kyiv : Redaktsiia chasopysu "Narodoznavstvo", 1997. 156 p. [in Ukrainian].

9. Stepanov O. Osnovy psykholohii i pedahohiky [Fundamentals of psychology and pedagogy]. Kyiv : Akademvydav, 2006. 520 p. [in Ukrainian].

10. Tyshchenko I. Ekzystentsial strakhu v romani R. Andriiashyka "Liudy zi strakhu" [Existential fear in R. Andriyashik's novel "People of Fear'. Theoretical and didactic philology]. Kyiv : DP 'Informatsiino-analitychne ahentstvo", 2011. Issue. 10. Pp. 374-384. [in Ukrainian].

11. Freyd Z. Sobranie sochineniy [Collection of works]: in 10 volumes. Moskva : STD, 2003-2008. Vol. 6: Hysteria and fear; [trans. with him. A. Bokovikova]. 2006. 320 p. [in Russian].

12. Yalom I. Vglyadyivayas v solntse. Zhizn bez straha smerti. [Peering into the sun. Life without fear of death]. Moskva: Eksmo, 2008. 352 p. [in Russian]. 